УДК 371.72(438)

\title{
ТЕОРЕТИКО-ПЕДАГОГІЧНІ ПЕРЕДУМОВИ РОЗВИТКУ ФІЗИЧНОГО ВИХОВАННЯ ДІТЕЙ ТА МОЛОДІ НА ПОЛЬСЬКИХ ЗЕМЛЯХ (ДРУГА ПОЛОВИНА ХІХ - ПОЧАТОК ХХ СТ.)
}

\author{
Володимир Пасічник ${ }^{1}$ \\ 1Університет Яна Кохановського в Кельцах, Філія в Пйотркуві Трибунальському, Польща, wlod_pas@o2.p1 \\ https://doi.org/10.29038/2220-7481-2019-04-32-37
}

\begin{abstract}
Анотації
У статті розкрито проблематику розвитку теоретичної думки польських учених, лікарів та суспільних діячів у галузі фізичного виховання дітей і молоді в другій половині XIX та початку XX ст. Проаналізовано основні концепції фізичного виховання в системі дошкільної та шкільної освіти на польських землях у цей історичний період. В основному увагу польських дослідників того часу зосереджено на впровадженні систематичних занять із фізичного виховання у всіх типах польських шкіл, застосування рухових ігор і забав у навчальному процесі, популяризації фізичної культури в закладах дошкільної освіти, залучення батьків у процес фізичного виховання дітей у родині, фаховій підготовці вчителів фізичної культури та ін. Мета дослідження - визначити основні напрями та тенденції розвитку теоретичної думки польських учених, лікарів і суспільних діячів у другій половині XIX - початку XX ст. у галузі фізичного виховання дітей та молоді. Методи дослідження - вивчення літературних джерел, документальних матеріалів, теоретичний аналіз і синтез отриманих даних. Результати дослідження. У другій половині XIX - на початку XX ст. проблематика фізичного виховання стала інтегральним елементом програм педагогічних з'їздів польських учителів на яких звертали увагу на надзвичайно важливу роль фізичного виховання в освіті молодого покоління, а також у покращенні стану здоров'я населення загалом. Польські вчені, педагоги лікарі брали активну участь у низці європейських конгресів і форумів, що відбувалися на початку XX ст., на яких розглядали проблеми фізичного виховання, здоров'я та гігієни дітей і молоді. Значну роль у популяризації в польському суспільстві питань фізичного виховання дітей та молоді відіграв IX з'ізд польських лікарів і біологів, який відбувся в 1900 р. в Кракові. Уперше під час проведення таких форумів організовано спеціальну секцію з проблематики фізичного виховання дітей і молоді. Висновки. Проведений аналіз літературних джерел та архівних документів дає підставу стверджувати, що, незважаючи на численні труднощі в процесі організації фізичного виховання в дошкільній і шкільній освіті на польських землях у цей історичний період (слабка матеріальна база для проведення занять із фізичного виховання; відсутність підготовлених учителів із цього предмету; консерватизм керівництва частини шкіл), теоретичний і практичний розвиток фізичного виховання підростаючих поколінь досягнув значного прогресу, порівняно з попередніми десятиріччями.
\end{abstract}

Ключові слова: фізичне виховання, теорія, школа, діти, шкільна молодь, учитель, розвиток.

Владимир Пасечник. Теоретико-педагогические предпосылки развития физического воспитания детей и молодёжи на польских землях (вторая половина XIX - начало XX в.). В статье раскрывается проблематика развития теоретической мысли польских ученых, врачей и общественных деятелей в области физического воспитания детей и молодёжи во второй половине XIX - в начале XX века. Анализируются основные концепции физического воспитания в системе дошкольного и школьного образования на польских землях в этот исторический период. В основном внимание польских исследователей того времени обращается на введение систематических занятий физического воспитания во всех типах школ, широкое использование подвижных игр в учебном процессе, популяризацию физической культуры в детских садах, привлечение родителей к процессу физического воспитания детей в семье, профессиональной подготовке учителей физической культуры и др. Цель исследования - определить основные направления и тенденции развития теоретической мысли польских ученых, врачей и общественных деятелей во второй половине XIX - в начале XX в. в области физического воспитания детей и молодежи. Методы исследования - изучение литературных источников, архивных документальных материалов, теоретический анализ и синтез полученных данных. Результаты исследования. Во второй половине XIX - в начале XX в. проблематика физического воспитания стала интегральным элементом программ педагогических съездов польских учителей, на которых обращалось внимание на исключительно важную роль физического воспитания в образовании молодого поколения, а также в подъёме уровня состояния здоровья населения в целом. Польские ученые, педагоги, врачи принимали активное участие в ряде европейских конгрессов и форумов, которые проходили в начале XX в., на которых рассматривались проблемы физического воспитания, здоровья и гигиены детей и молодежи. Значительную роль в популяризации в польском обществе физического воспитания детей и молодежи сыграл IX съезд 
польских учителей и биологов, который состоялся в 1900 г. в Кракове. Впервые во время проведения таких форумов было организовано специальную секцию с проблематики физического воспитания детей и молодежи. Bblвodb. Проведенный анализ литературных и архивных документов позволяет утверждать, что, несмотря на многочисленные трудности в процессе организации физического воспитания в дошкольном и школьном образовании на польских землях в этот исторический период (слабая материальная база для проведения занятий физического воспитания; отсутствие подготовленных учителей этого предмета; консерватизм руководства некоторых школ), теоретическое и практическое развитие физического воспитания подрастающих поколений достигло значительного прогресса по сравнению с предыдущими десятилетиями.

Ключевые слова: физическое воспитание, теория, школа, дети, молодежь, учитель, развитие.

Volodymyr Pasichnyk. Theoretical and Pedagogical Prerequisites for the Development of Physical Education of Children and Youth on Polish Lands (the Second Half of the $\mathbf{1 9}^{\text {th }}-$ the Early $20^{\text {th }}$ Century). The scientific paper is devoted to the problems of the development of theoretical thought of Polish scientists, doctors and public figures in the field of physical education of children and youth in the second half of the $19^{\text {th }}-$ the early $20^{\text {th }}$ century. The basic concepts of physical education in the system of preschool and school education on Polish lands in this historical period are analysed. The attention of Polish researcher during that time was mainly focused on the introduction of systematic physical education classes in all types of schools, use of mobile games in the educational process, the popularization of physical education in kindergartens, the involvement of parents in the process of physical education of children in the family, vocational training and training of physical education teachers and others. The Purpose of the Study. Determination of the main directions and trends in the development of theoretical thought of Polish scientists, doctors and public figures in the second-half of the $19^{\text {th }}$-the early $20^{\text {th }}$ century in the field of physical education of children and youth. Research Methods are the study of literary sources, archival documentary materials, methods of theoretical analysis and synthesis of the data. The Results of the Study. In the second half of the $19^{\text {th }}-$ early $20^{\text {th }}$ centuries the problem of physical education became an integral element of the programs of pedagogical congresses of Polish teachers, which drew attention to the exceptionally important role of physical education in the education of the younger generation, as well as in general raising the health level of the population. Polish scientists, educators, doctors took an active part in number of European Congress and Forums that were held in the early twentieth century, which addressed the problems of physical education, health and hygiene of children and young people. The $9^{\text {th }}$ Congress of Polish teachers and biologists, which took place in 1900 in Krakow, played a significant role in popularizing the physical education of children and youth in the Polish society. During such forums, a special section was firstly organized on the subject of physical education of children and youth. Conclusions. The analysis made suggests that despite the many difficulties in the process of organizing physical education in preschool and school education on Polish lands during this historical period (weak material basis for conducting physical education classes; lack of trained teachers of this subject; conservatism of the management of some schools). The practical development of physical education of the younger generations has made significant progress compared to previous decades.

Key words: physical education, theory, school, children, youth, teacher, development.

Вступ. У другій половині XIX - на поч. XX ст. на польських землях здійснено низку важливих реформ шкільної системи освіти. У цьому процесі одне з провідних місць займали фізичне виховання та шкільна гігієна. Значно зросла свідомість суспільна в розумінні того, що, власне, правильно організований процес фізичного виховання та дбання про гігієну в школі є підставою їхнього успішного навчання й виховання дітей і молоді. На цьому фоні одночасно з розвитком вікової психології та експериментальної педагогіки щораз більшу роль почали відігрівати теорія та практика фізичного виховання. Цей предмет шкільної програми стає обов'язковим у школі, з'являються посади вчителя фізичного виховання та шкільного лікаря (лікар гігієни).

Польська теорія та практика фізичного виховання дітей і молоді має багаті традиції. Її засновниками вважаються С. Петрици, А. Моджевський, В. Очко. Їхні погляди та ідеї розвинуті в працях і шкільній практиці А. Снядецького, Г. Пірамовича, Л. Барковського, Т. Чацького, Л. Голембіовського, Е. Естковського й ін. Значну роль у розвитку теорії та практики шкільного фізичного виховання на польських землях відіграла також діяльність Комісії народної освіти (1773-1794).

Мета дослідження - висвітлити основні напрями та тенденції розвитку теоретичної думки польських учених, лікарів і суспільних діячів у другій половині XIX та початку XX ст. у галузі фізичного виховання дітей і молоді.

Методи дослідження - вивчення літературних джерел, документальних й історичних матеріалів, теоретичний аналіз і синтез отриманих даних.

Результати дослідження. Під кінець ХІХ ст. теорія фізичного виховання дітей і молоді на польських землях набирала все більш чітких рис, становлячись новою науковою дисципліною. Психофізичний розвиток людини представники цієї наукової дисципліни сприймали в таких аспектах, як функціо- 
нальний, розвиток сили та гнучкості тіла, що давало змогу брати активну участь у суспільному житті. Значну роль у цей історичний період у популяризації фізичного виховання серед дітей і молоді відігрівала діяльність таких товариств й організації, як Товариство гімнастичне «Сокіл», Товариство підтримки фізичного розвитку жінок та дітей, Комісія рухових ігор і забав.

У польській педагогічній думці, як і в західноєвропейській педагогіці, відчутне зацікавлення викликала проблематика фізичного виховання дітей дошкільного віку. Серед польських теоретиків фізичного виховання цією проблемою займалася М. Верихо-Радзивіловічова (1864-1944), польська письменниця, педагог, автор відомої праці «Гімнастика для дітей у віці 4-9 років». Підручник для батьків $\mathrm{i}$ вихователів», виданий у Варшаві в 1887 р. (це був перший на польських землях підручник із цієї проблематики), та «Товариські ігри і забави в приміщенні та на свіжому повітрі» (1890р.). На думку вченої, зорганізовані рухливі гри й забави не лише сприяють фізичному розвитку дітей, але водночас $\epsilon$ засобом виховання, формуючи основні навики та форми їхньої поведінки. М. Верихо-Радзивіловічова звертала увагу на те, що тогочасна гімнастика для дітей дошкільного віку не була надто цікавою формою фізичного виховання, але підкреслювала її значення для розвитку дошкільників. Вона зазначала також суттєвість індивідуального підходу до дитини залежно від рівня їхньої фізичної готовості. Пропонувала імітаційні фізичні рухи, у яких діти мали можливість наслідувати рухи людей і птахів, що перетворювало нудні вправи в цікаву забаву. Рухливі ігри та забави, як писала М. Верихо-Радзивіловічова, впливають на пізнавальний розвиток дитини, формують іiі суспільно-моральні постави й емоції, сприяють усебічному розвитку ії особистості [3].

Рухливі ігри й забави М. Верихо-Радзивіловічова вважала основною формою фізичного виховання дітей дошкільного віку. Усі фізичні вправи педагог поділила на п’ять груп: 1) вправи для рук; 2) вправи для ніг; 3) вправи для тулуба; 4) комбіновані вправи; 5) біг. Для дітей молодших дошкільних груп запропоновано натуральні форми фізичного виховання, як-от: ходьба, біг, метання, а для старших дошкільнят - вправи, що розвивали координацію руху. Основною частиною заняття повинна бути гімнастика. М. Верихо-Радзивіловічова можна вважати засновницею методики фізичного виховання в польських дошкільних закладах [3].

У другій половині XIX - на початку XX ст. у польській педагогічній літературі та літературі 3 фізичного виховання тривала дискусія стосовно ролі рухливих ігор у психофізичному розвитку дітей. Визначилися дві групи дослідників. Перша була переконана в тому, що дитина має бути повністю здоровою й справною, для цього достатньо використовувати в навчально-виховному процесі в школі т.3. натуральні форми рухової активності (з елементами ходьби, бігу, стрибків, плавання, різноманітні рухливі ігри та забави). Панувало переконання, що діти в 7-8 років життя не обов'язково повинні систематично виконувати фізичні вправи, їм достатньо брати участь у рухливих іграх і забавах. Друга група педагогів і науковців була переконана в необхідності організації для дітей дошкільного та молодшого шкільного віку систематичних занять із гімнастики, хоч вони одночасно вважали, що рухливі ігри й забави $\epsilon$ також суттєвим елементом психофізичного розвитку дітей, який у комплексі з гімнастикою створював оптимальні можливості для їх усебічного розвитку. Перших і других педагогів і вчених поєднувало розуміння важливості застосування рухливих ігор та забав на свіжому повітрі та в кожну пору року. Особливо цінними вважалися групові ігри, а також можливість самих дітей, обирати собі такі ігри й забави, які їм подобались [4].

Суттєвий внесок у розвиток фізичного виховання дітей і молоді та шкільної гігієни здійснив Е. Мадейський (1832-1906), випускник Віденського університету, лікар, педагог, викладач гімнастики й шкільної гігієни, автор праці «Раціональна гімнастика» (1871р.) і перших польських підручників із гімнастики для слухачів учительських семінарських курсів «Гімнастика в народних школах. Інструкція для вчителів» (1879 р.) та «Навчання гімнастики в школі. Теоретичний підручник для слухачів вчительських семінарів» (1890р.) [1]. Е. Мадейський зосередив свою увагу на ефективності впливу фізичних вправ на дитину, які пропонував виконувати раціонально, тобто враховуючи їх користь для зміцнення організму, біологічні потреби дітей у руховій діяльності. Його праця підкреслювала єдність фізичного виховання з правильним розвитком особовості людини. Він також зазначав, що оздоровчорозвивальні можливості фізичних вправ визначають суспільну роль фізичного виховання.

Проблематика фізичного виховання дітей і молоді займала провідне місце в педагогічній теоріях Я. В. Давида (1859-1914) та С. Карповича (1864-1921). Необхідність фізичної активності молоді Давид обгрунтовував цивілізаційним поступом, технологічним та урбанізаційними процесами, які відбувались у суспільстві промислових країн [8].

С. Карпович є автором праці «Виховне значення рухових забав» (1905р.). Це була одна з найбільш прогресивних книг про фізичне виховання дітей та молоді того часу. На думку автора, значення 
рухових забав полягало на синтезі трьох компонентів - фізіологічних, психологічних і суспільних. Як відзначав С. Карпович, із погляду фізіологічного бачення, рухливі ігри повинні бути так підібрані, щоб у руховій діяльності по черзі брали участь усі частини тіла, що є підставою до рівномірного обтяження організму. Ігри й рухові забави теж є підставою психічного розвитку дитини, сприяють розвитку спостережливості, уваги, швидкій реакції. Суспільна функція ігор і рухових забав полягає в колективній участі дітей у цих формах фізичної активності; діти в натуральних умовах навчаються вміння взаємодії, осягнення спільних цілей, набувають нові досвідчення в спілкуванні. С. Карпович визначив методичні рекомендації заложення організації ігор і рухових забав для дітей та молоді: 1) свобода руху; 2) урахування фаз психофізичного розвитку дітей і молоді; 3) зацікавлень; 4) активна участь учителя. С. Карпович передбачав, що роль рухливих ігор буде щораз більш суттєвою в протистоянні недоліків, пов'язаних із біологічними та психічними хворобами людини [7].

Багато уваги фізичному вихованню в школі приділяв у своїх працях Г. Гігер (1866-1942), лікар, невролог і психіатр, який вважав, що суттєвою вадою тодішньої системи шкільного навчання та виховання була повна домінація в шкільних програмах інтелектуального розвитку учнів з одночасним занедбанням, а часто й нехтуванням їхнього фізичного розвитку. Дослідник критикував переважаючий серед керівництва шкіл погляд, що однієї години фізичного виховання повністю достатньо для правильного фізичного розвитку учнів, що, на думку Г. Гігера, ураховуючи обсяг біологічних потреб у русі для школярів, $є$ недопустимо. Він також рішуче критикував німецьку й шведські системи гімнастики, вважаючи, що для розвитку дитини найважливіша організація рухливих ігор на свіжому повітрі, яких гімнастика не може повністю замінити. Розуміючи складність переходу від тогочасної системи фізичного виховання в школах із його перенасиченням у навчальних програмах із цього предмету гімнастичними вправами, пропонував упровадження інших засобів з обов'язковим урахуванням згоди шкільного лікаря на виконування окремих фізичних вправ відповідно до стану здоров'я учнів та їхніх фізичних можливостей. Г. Гігнер, випереджуючи свій час, стверджував, що школи повинні мати спортивні зали 3 огріванням, освітленням, вентиляцією для проведення повноцінного навчального процесу з фізичного виховання, створення комфортних умов для занять учнів [7].

Особливу увагу польськими педагогами, лікарями та вченими (С. Бержанський. Г. Верніц, С. Камінський) звернуто на проблему фізичного виховання дівчат. У статтях, опублікованих у часописі «Огляд педагогічний» у другій половині 80 -х років XIX ст., звернуто увагу на причини занедбання фізичного виховання дівчат уже від їх народження. Однією з головних причин цього стану був консерватизм польського суспільства, що опирався на застарілих і патріархальних поглядах на виховання жінок і їх ролі та місця в суспільному житті. Прогресивні суспільні діячі, учителі рішуче виступали за негайне впровадження обов'язкових фізичних занять із фізичного виховання у всіх жіночих навчальних закладах, у тому числі й у приватних.

Польські вчені, педагоги лікарі (Х. Кучальська, В. Козловський, Е. Пясецький та ін.) брали активну участь у низці європейських конгресів і форумів, що відбувалися на початку XX ст. На них розглядали проблеми фізичного виховання, здоров’я й гігієни дітей та молоді. На цих конгресах і форумах визначалися напрями розвитку європейського фізичного виховання, його завдання, підкреслювалася важливість застосування у фізкультурно-освітянському процесі різнорідних форм, між іншим, ігор i рухливих забав, спорту й туризму, особливо в промислових регіонах континенту. Значне місце під час роботи конгресу займали новаторські практичні покази проведення занять із фізичного виховання 3 використанням нового спортивного інвентарю. На початку цього століття проблематика фізичного виховання стала також інтегральним елементом програм педагогічних з'їздів польських учителів [2].

Значну роль у популяризації в польському суспільстві фізичним вихованням дітей і молоді відіграв IX з’їзд польських лікарів та біологів, який відбувся в 1900 р. в Кракові. Уперше під час проведення таких форумів відкрито спеціальну секцію з проблематики фізичного виховання. Учасники з'їзду звернули увагу на надзвичайно суттєву роль фізичного виховання в освіті молодого покоління, а також у піднесенні стани здоров'я населення загалом. Унесено пропозицію щодо обов'язкового впровадження для школярів рухливих ігор і забав на свіжому повітрі, організації краєзнавчих екскурсій, популяризації в школі плавання. Лікарі та педагоги, в умовах недостатньої кількості в школі гімнастичних залів, спортивного обладнання, відповідної кількості кваліфікованих учителів фізичної культури звернули особливу увагу на проведення в цих умовах краєзнавчих екскурсій як засобу зміцнення здоров'я дітей $\mathrm{i}$ молоді [7].

У подальшому розвитку теорії та практики фізичного виховання школярів потрібно відзначити працю Х. Вітковського «Кілька слів про гімнастику», метою якої була популяризація фізичного виховання серед польського населення, ще недостатньо в той час підготовленого й обізнаного в цьому 
питанні. Автор у цій праці посилається на стародавніх, але також і на сучасних мислителів та лікарів, які намагалися вияснити сутність і значення гімнастики в житті людини та суспільства. Х. Вітковський зазначав, що ідеал здоров'я, краси й сили можна досягти лише шляхом гармонійного розвитку духовних і фізичних сил людини. Умовою для цього є заспокоєння натуральної потреби людини в русі. Ця потреба, як і стан здоров'я населення, а також прискорений промисловий розвиток суспільства, визначає головну функцію фізичних вправ, що полягає в розвитку й зміцненні психічного та фізичного здоров'я людини [2; 6].

Також важливу роль у розвитку фізичного виховання на польських землях відіграв Г. Йордан (1842-1907), професор медицини Краківського університету. Проблематику фізичного виховання молоді Х. Йордан розкривав із погляду лікаря. Особливо важливе місце у фізичному розвитку молоді, на думку Г. Йордана, займає фізична активність молоді в позаурочному часі. Саме ці погляди привели до ідеї відкриття для дітей і молоді спеціальних міських парків, де б вони могли займатися фізичними вправами на спеціальних спортивних майданчиках (гімнастика, теніс, футбол, рухливі ігри). Ця ідея реалізована в 1889 р., коли перший такий парк відкрито в Кракові. Незважаючи на те, що молодь займалася фізичними вправами у вільний від уроків або праці час, ці заняття мали організований характер, чому значну увагу приділяв Г. Йордан. У 1891 р. парк Г. Йордана в Кракові відвідали 13 тис. хлопців і дівчат, а в 1901 р. - 32000 тис. [5].

Програма занять складалася з рухливих та спортивних ігор й індивідуальних занять, а також із гімнастичних вправ для дітей і молоді 5-18 років життя. Заняття були так заплановані, щоб їх учасники могли по черзі змінювати майданчики. У парку існував внутрішній регламент, що визначав засади участі в заняттях. Дбаючи про здоров’я та гігієну дітей і молоді, організатори побудували також душові приміщення.

Відкриття парку Х. Йордана як осередку фізичної активності й рухової рекреації дітей і молоді у вільний від занять та праці час мало винятково важливе значення для польської практики фізичного виховання. Незабаром парки Йордана почали відкриватися в багатьох польських містах (Варшава, Ченстохова, Цешин, Новий Сонч, Плоцьк, Люблін, Каліш та ін.). Потрібно відзначити, що парки лише частково були фінансовані з державних фондів, в основному кошти на їх утримання давали приватні суспільні організації й прогресивні суспільні діячі та підприємці, які усвідомлювали значення цих об’єктів для всебічного фізичного розвитку польської молоді. Незабаром зацікавленість цими об'єктами почали проявляти також школи [2].

Г. Йордан був переконаний у виховному позитивному значенні рухових забав та ігор для дітей і молоді. Свої погляди на цю тему він виклав у статті «Про фізичну активність молоді». Він уболівав, що в більшості навчальних закладів рухливі ігри не сприймаються як надзвичайно важлива форма фізичного виховання, підкреслюючи, що вони реалізовують дві важливі функції - зміцнення здоров'я та виховну. На думку Г. Йордана, правильна організація вільного часу для дітей і молоді спрямована на виконання фізичних вправ на свіжому повітрі, зменшує негативний вплив на перевантажених навчальним матеріалом учнів. Крім того, рухливі ігри формують у молоді необхідні якості, які потрібні в дорослому житті; готують їх до участі в суспільному житті. Безсумнівно, як на той час парки Г. Йордана були сучасними осередками фізичного виховання та рекреації польської молоді (дещо пізніше використовуючи основні положення цієї концепції, почали відкриватися парки ім. В. Рау) [6].

Зазначимо, що Г. Йордан був ініціатором упровадження до програм середніх шкіл Кракова обов'язкових занять із гімнастики та введення посади шкільного лікаря. Був також палким прихильником створення системи фахової підготовки вчителів фізичної культури.

Одним із найбільш видатних теоретиків фізичного виховання того часу був Е. Пясецький, у 20-х роках XX ст. декан факультету фізичного виховання Познанського університету на медичному відділі, де готували вчителів фізичної культури, автор праці «Засади фізичного виховання» (1904р.). У свій час Е. Пясецький тривалий час працював учителем фізичної культури в школі, чудово знав потреби шкільного фізичного виховання. У цій праці Е. Пясецький здійснив аналіз впливу фізичних вправ на психофізичний розвиток людини. Особливу увагу автор приділяв рухливим іграм на свіжому повітрі в контексті фізичного виховання молоді. Одночасно Е. Пясецький підкреслював значення систематичності виконування фізичних вправ дітьми й молоддю.

Особливу роль у формуванні польської теоретичної думки в галузі фізичного виховання відіграв часопис «Рух» (Варшава, 1906-1915рр.). Засновником і редактором «Руху» був В. Козловський (18661915), головний інструктор парків ім. Е. Рау у Варшаві, прихильних шведської гімнастичної системи. Р. Козловський критикував схематизм у фізичному вихованні, був прихильником широкого й різноманітного спектра фізичних вправ. Головним завданням «Руху» була популяризація фізичного вихован- 
ня та пошуку нових шляхів удосконалення методики фізичного виховання в школі. На шпальтах часопису висвітлювалися найважливіші тогочасні проблеми фізичного виховання: національні традиції фізичного виховання та спорту; наукові підстави виховання й оздоровчі вартості фізичних вправ, їх позитивного впливу на розвиток дітей та молоді, методики рухливих ігор. Багато місця відводив «Рух» шкільному фізичному вихованню, навчанню фізичних вправ, проблематиці шкільної гігієни, оснащення шкіл спортивним обладнанням, приладами та ін. Публікувалися також статті щодо організації уроків фізичного виховання, тим самим сприяючи піднесенню кваліфікаційного рівня вчителів. У часописі часто публікувалися матеріали щодо найважливіших подій, що відбувались у фізичній культурі та спорті на польських землях, у Свропі та світі [2; 8].

Висновки. Розвиток теорії й практики фізичного виховання дітей і молоді в другій половині XIX на початку XX ст. на польських землях зумовлений інтенсивним господарчим, технологічним, суспільним розвитком країни й процесами урбанізації.

Особливу увага польські педагоги, лікарі та вчені приділяли проблемам фізичного виховання дітей дошкільного віку та дівчат. Відзначалася суттєвість інтенсифікації фізичного виховання дітей у дошкільних закладах, здійснено ретельний аналіз причини занедбання фізичного виховання серед дівчат. Підкреслювалася необхідність негайного впровадження обов'язкових занять із фізичного виховання у всіх жіночих навчальних закладах, у тому числі й у приватних.

Польські вчені, педагоги лікарі брали активну участь у низці європейських конгресів та форумів, що відбувалися наприкінці XIX - на поч. XX ст., на яких розглядали проблеми фізичного виховання, здоров'я й гігієни дітей і молоді. На цих конгресах та форумах визначалися напрями розвитку європейського фізичного виховання, його завдання, підкреслювалася важливість різнорідних форм фізичного виховання, інших рухливих ігор, спорту й туризму, особливо в промислових регіонах континенту.

Важливу роль для польської теорії та практики фізичного виховання кінця XIX та початку XX ст. відіграли парки Х. Йордана та ім. В. Рау як осередки фізичної активності й рухової рекреації дітей і молоді у вільному від занять та праці часі.

\section{Джерела та література}

1. Dolata E. Galicyjscy popularyzatorzy zdrowia i higieny przełomu XIX i XX wieku, Lubelski Rocznik Pedagogiczny. T. XXXV. Z. 4, 2016. S. 79-95.

2. Gaj J., Hądzełek K. Dzieje kultury fizycznej w Polsce. Poznań, 1997. S. 61, 293.

3. Leżańska W., Wychowanie fizyczne w pedagogice Marii Werycho-Radziwiłłowiczowej. Początki gimnastyki w przedszkolach polskich. Journal of Modern. T. 1, Nr. 36. 2008. S. 11-26.

4. Nawrot-Borowska M., Zabawy dzieci polskich w drugiej połowie XIX i na początku XX wieku w świetle zapatrywań teoretycznych. Biuletyn Historii Wychowania. 2013. Nr 30. S. 65-88.

5. Pięta J. Pedagogika czasu wolnego. Warszawa: Wyd. FREL, 2014. S. 254.

6. Smarzyński H., Henryk Joradan - pionier nowoczesnego wychowania fizycznego w Polsce. Kraków: PWN, 1958. S. 258.

7. Szymański L., Higiena i wychowanie fizyczne w szkolnictwie ogólnokształcących w Królestwie Polskim 1815-1915. Wrocław: PWN, 1979. S. 303.

8. Wroczyński R., Powszechne dzieje wychowania fizycznego i sportu. Zakład Narodowy imienia Ossolińskich. Wrocław;Warszawa, 1985.

\section{References}

1. Dolata, E. (2016). Galicyjscy popularyzatorzy zdrowia i higieny przelomu XIX i XX wieku, Lubelski Rocznik Pedagogiczny, T. XXXV, z. 4, 79-95.

2. Gaj, J., Hądzełek, K. (1997). Dzieje kultury fizycznej w Polsce, Poznań, 61, 293.

3. Leżańska, W. (2008). Wychowanie fizyczne w pedagogice Marii Werycho-Radziwiłłowiczowej. Początki gimnastyki w przedszkolach polskich. Journal of Modern, T. 1, Nr. 36, 11-26.

4. Nawrot-Borowska, M. (2013). Zabawy dzieci polskich w drugiej połowie XIX i na początku XX wieku w świetle zapatrywań teoretycznych, Biuletyn Historii Wychowania, $\mathrm{Nr}$ 30, 65-88.

5. Pięta, J. (2014). Pedagogika czasu wolnego. Warszawa: Wyd. FREL, 254.

6. Smarzyński, H. (1958). Henryk Joradan - pionier nowoczesnego wychowania fizycznego w Polsce. Kraków: PWN, 258.

7. Szymański, L. (1979). Higiena i wychowanie fizyczne w szkolnictwie ogólnokształcących w Królestwie Polskim 1815-1915. Wrocław: PWN, 303.

8. Wroczyński, R. (1985). Powszechne dzieje wychowania fizycznego i sportu, Zakład Narodowy imienia Ossolińskich, Wrocław;Warszawa.

Стаття надійшла до редакції 30.09.2019 р. 